\title{
On the importance of initial conditions for simulations of the Mid-Holocene climate
}

\author{
H. Renssen ${ }^{1}$, E. Driesschaert ${ }^{2}$, M. F. Loutre ${ }^{2}$, and T. Fichefet ${ }^{2}$ \\ ${ }^{1}$ Faculty of Earth and Life Sciences, Vrije Univ. Amsterdam, De Boelelaan 1085, 1081 HV Amsterdam, The Netherlands \\ ${ }^{2}$ Institut d'Astronomie et de Géophysique G. Lemaître, Univ. Catholique de Louvain, 2 Chemin du Cyclotron, \\ 1348 Louvain-la-Neuve, Belgium
}

Received: 24 May 2006 - Published in Clim. Past Discuss.: 28 June 2006

Revised: 29 August 2006 - Accepted: 15 September 2006 - Published: 19 September 2006

\begin{abstract}
Three simulations of the Mid-Holocene (6 ka) climate were performed with the ECBilt-CLIO-VECODE coupled atmosphere-ocean-vegetation model to study the impact of initial conditions. These experiments were forced with identical $6 \mathrm{ka}$ forcings (orbital parameters and atmospheric greenhouse gas concentrations) and differed only in initial conditions. Two simulations were designed as equilibrium experiments, with one being initialized with preindustrial conditions as required by the protocol of the Paleoclimate Modelling Intercomparison Project (PMIP), while in a second experiment early Holocene $(9 \mathrm{ka})$ initial conditions were used. These equilibrium simulations were run for 2100 years with $6 \mathrm{ka}$ forcings. The third experiment was set up as a transient simulation, also starting from early Holocene conditions, but forced with annually changing orbital parameters and greenhouse gas levels. The results of the last 100 years are compared and reveal no statistically significant differences, showing that in this model the initial conditions have no discernible impact on the $6 \mathrm{ka}$ climate. This suggests that the PMIP set-up for $6 \mathrm{ka}$ simulations is valid, with the condition that spin-up phase should be long enough (at least 550 years) to allow the deep ocean to adjust to the change in forcings.
\end{abstract}

\section{Introduction}

The Mid-Holocene $(6 \mathrm{ka})$ is frequently used as a reference period to evaluate the sensitivity of climate models to changes in radiative forcing, e.g., in the first and second phases of the Paleoclimate Modelling Intercomparison Project (PMIP, Joussaume and Taylor, 2000; Crucifix et al.,
2005). Within PMIP, all models use an identical experimental setup to make intermodel comparisons possible (e.g., Joussaume et al., 1999). The PMIP experimental setup for Mid-Holocene simulations includes the forcing conditions and model spin-up. Compared to preindustrial forcings, the orbital parameters and atmospheric greenhouse gas concentrations are changed to represent conditions at $6 \mathrm{ka}$. The spinup procedure requires models to start with initial conditions obtained from a model state in quasi-equilibrium with preindustrial forcings. After completion of the experiments in PMIP, the model results are evaluated by comparison with proxy data (e.g., Prentice et al., 1998; Joussaume et al., 1999). A key region for model-data comparisons is Northern Africa, which experienced a much wetter climate at $6 \mathrm{ka}$ than today under influence of the orbitally forced enhancement of the summer monsoons (i.e. "green" Sahara).

The choice of the preindustrial initial conditions for $6 \mathrm{ka}$ experiments is disputable, as potentially a different 6-ka climate state can be obtained when different initial conditions are used. Possibly, the use of early Holocene (e.g., 9 ka) initial conditions is more appropriate because the climate of that time could have been closer to the mid-Holocene climate. This could for instance be the case in the Sahara/Sahel region that was in a 'green' state in the early-to-mid Holocene (from $\sim 11$ to $5 \mathrm{ka}$ ) during the so-called African Humid Period (e.g., deMenocal et al., 2000), which includes the $6 \mathrm{ka}$ time-slice (e.g., Hoelzmann et al., 1998; Prentice et al., 2000). Previous model studies have suggested that both the green and desert states could have been stable under $6 \mathrm{ka}$ forcings (Renssen et al., 2003), implying that potentially simulations initialized with preindustrial conditions could produce a desert state in Northern Africa instead of the required green state.

Correspondence to: H. Renssen

(hans.renssen@geo.falw.vu.nl)

Published by Copernicus GmbH on behalf of the European Geosciences Union. 
(a) 9 ka minus preindustrial initial states

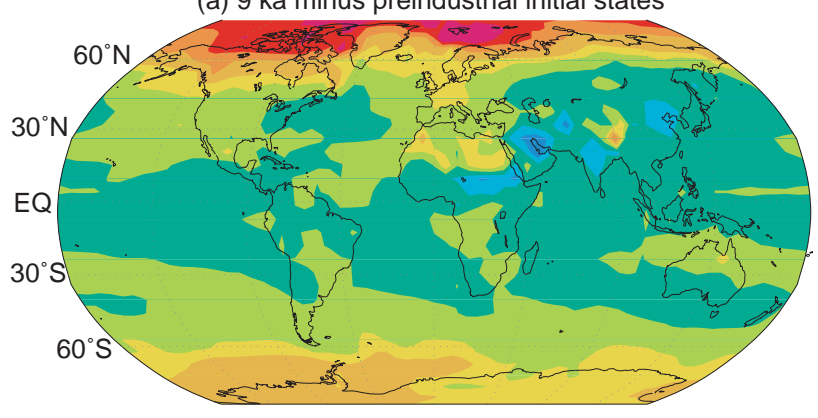

(b) 6 ka final minus preindustrial initial states

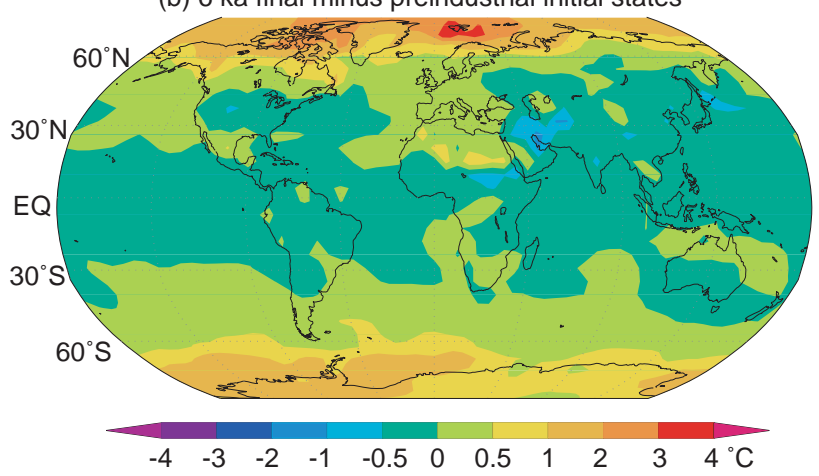

Fig. 1. Simulated annual mean surface temperature anomalies (in ${ }^{\circ}$ C). (a) $9 \mathrm{ka}$ minus preindustrial initial states, (b) $6 \mathrm{ka}$ final state (from 6kPI) minus preindustrial initial state.

To study the influence of the initial conditions on the simulated 6-ka climate, we compare here the results of three simulation experiments performed with the ECBiltCLIO-VECODE model, which describes the global coupled atmosphere-ocean-vegetation system. In addition to an experiment with the "standard" PMIP setup (i.e. preindustrial initial conditions), we have performed an experiment with $6 \mathrm{ka}$ forcings that is initialized with conditions derived from a simulation in quasi equilibrium with forcings for $9 \mathrm{ka}$. These two experiments are compared with $6 \mathrm{ka}$ results from a transient experiment that is integrated forward in time, forced with annually varying orbital and greenhouse gas forcing and starting from the same $9 \mathrm{ka}$ initial conditions.

\section{Model and experimental setup}

We applied version 3 of the ECBilt-CLIO-VECODE coupled climate model of intermediate complexity. The atmospheric model is ECBilt, a quasi-geostrophic model with T21-L3 resolution (Opsteegh et al., 1998). CLIO is the oceanic component and consists of a free-surface, primitive-equation ocean general circulation model (OGCM), coupled to a dynamicthermodynamic sea-ice model (Goosse and Fichefet, 1999). The OGCM includes 20 levels in the vertical and has a $3^{\circ} \times 3^{\circ}$ latitude-longitude horizontal resolution. VECODE is a model that simulates the dynamics of two main terrestrial plant functional types, trees and grasses, and desert as a dummy type (Brovkin et al., 2002). Details about the model are available at http://www.knmi.nl/onderzk/CKO/ ecbilt.html.

With an earlier version of the model (i.e. version 2), we studied the Holocene climate evolution in Northern Africa (Renssen et al., 2003). Compared to version 2, the present model version 3 simulates a climate that is closer to modern observations. The most important improvements in version 3 are a new land surface scheme that takes into account the heat capacity of the soil, and the use of isopycnal diffusion as well as Gent and McWilliams parameterization to represent the effect of meso-scale eddies in the ocean (Gent and McWilliams, 1990). The differences between versions 2 and 3 are further discussed at http://www.knmi.nl/onderzk/CKO/ differences.html.

With ECBilt-CLIO-VECODE-version-3 we performed two equilibrium 6 ka experiments in which identical changes in forcings are applied relative to a standard set of preindustrial conditions. The most important change is the modification of the orbital parameters to their 6-ka values (Table 1) according to Berger (1978). In addition, to account for different values in atmospheric trace gas concentrations at $6 \mathrm{ka}$, the levels of $\mathrm{CO}_{2}, \mathrm{CH}_{4}$ and $\mathrm{N}_{2} \mathrm{O}$ were set at $267.6 \mathrm{ppm}$, $589.1 \mathrm{ppb}$ and $262.3 \mathrm{ppb}$, respectively (Raynaud et al., 2000). The two experiments were run with these forcings for 2100 years, starting from different initial conditions. The first experiment (hereafter "6kPI") was started from a state obtained from a 2500-year control run with preindustrial conditions in accordance with the PMIP protocol, while a second simulation (hereafter "6k9k") was initialized with a state derived from a 1500-year long experiment with orbital and greenhouse gas forcings for $9 \mathrm{ka}$ (Table 1).

As expected, the 9-ka initial state is generally warmer than the preindustrial initial state (Table 2, Fig. 1a), especially at high latitudes. According to our model, the annual mean temperature at $9 \mathrm{ka}$ was 1 to $5^{\circ} \mathrm{C}$ above the preindustrial level in the Arctic and 0.5 to $2^{\circ} \mathrm{C}$ at southern high latitudes. At high latitudes, the annual mean temperature anomaly is governed by the insolation difference during particular seasons, i.e. June-July in the Northern Hemisphere (Renssen et al., 2005a) and September-October in the Southern Hemisphere (Renssen et al., 2005b). During these seasons, the positive insolation difference between $9 \mathrm{ka}$ and today was at its maximum at high latitudes $\left(+60 \mathrm{Wm}^{-2}\right.$ at $60^{\circ} \mathrm{N}$ in June, and $+37 \mathrm{Wm}^{-2}$ at $60^{\circ} \mathrm{S}$ in October). In polar regions the warming effect of this forcing is amplified by various strong positive feedbacks, i.e. the snow and sea ice albedotemperature feedback, the sea ice-insulation feedback, and the tundra-taiga feedback (only relevant over Northern Hemisphere continents). In addition, part of the excess heat is stored in the oceans due to their large heat capacity. As a result, at $9 \mathrm{kaBP}$, the high-latitude oceans are warmer than 
Table 1. Overview of forcings for $9 \mathrm{ka}, 6 \mathrm{ka}$ and preindustrial conditions. The $9 \mathrm{ka}$ and preindustrial forcings were used in equilibrium experiments performed to obtain initial conditions for experiments $6 \mathrm{k} 9 \mathrm{k}$ and $6 \mathrm{kPI}$, respectively. In the experiments $6 \mathrm{k} 9 \mathrm{k}$ and $6 \mathrm{kPI}$, the forcings for $6 \mathrm{ka}$ were prescribed.

\begin{tabular}{ccccccc}
\hline & \multicolumn{2}{c}{ Orbital parameters } & \multicolumn{3}{c}{ Atmospheric trace gas levels } \\
\hline & Eccentricity & Obliquity $\left(^{\circ}\right)$ & Longitude of perihelion & $\mathrm{CO}_{2}(\mathrm{ppm})$ & $\mathrm{CH}_{4}(\mathrm{ppb})$ & $\mathrm{N}_{2} \mathrm{O}(\mathrm{ppb})$ \\
\hline $9 \mathrm{ka}$ & 0.019280 & 24.229 & 311.26 & 261.9 & 650.0 & 262.3 \\
$6 \mathrm{ka}$ & 0.018682 & 24.105 & 0.87 & 267.6 & 589.1 & 262.3 \\
Preindustrial & 0.016724 & 23.446 & 102.04 & 277.4 & 735.4 & 276.4 \\
\hline
\end{tabular}

Table 2. Annual mean values for some key variables for the $6 \mathrm{ka}$ climates simulated in the three experiments. For $6 \mathrm{kPI}$ and $6 \mathrm{k} 9 \mathrm{k}$, the averages over the last 100 years of the 2100-year long simulations are shown, while for 6kTR the 100-year means for the 6050-5950 yr BP period are presented. The standard deviations for 6kPI are given between brackets for the 6 ka climate (i.e., the last 100 years of the simulation). For comparison, also the initial values for $6 \mathrm{kPI}$ and $6 \mathrm{k} 9 \mathrm{k}$ are shown.

\begin{tabular}{lccccc}
\hline & \multicolumn{5}{c}{ Experiments } \\
& & $6 \mathrm{kPI}$ & & $6 \mathrm{k} 9 \mathrm{k}$ & $6 \mathrm{kTR}$ \\
\hline & Init & $6 \mathrm{ka}$ & Init & $6 \mathrm{ka}$ & $6 \mathrm{ka}$ \\
\hline Global ocean variables & & & & & \\
Global ocean temperature $\left({ }^{\circ} \mathrm{C}\right)$ & 3.07 & $3.11(0.001)$ & 3.12 & 3.11 & 3.11 \\
Global surface temperature $\left({ }^{\circ} \mathrm{C}\right)$ & 15.80 & $15.94(0.08)$ & 16.03 & 15.94 & 15.93 \\
Sea-ice volume $\mathrm{NH}\left(10^{3} \mathrm{~km}^{3}\right)$ & 43.2 & $27.8(1.7)$ & 19.2 & 28.0 & 27.8 \\
Sea-ice volume $\mathrm{SH}\left(10^{3} \mathrm{~km}^{3}\right)$ & 11.8 & $10.4(0.7)$ & 10.4 & 10.5 & 10.7 \\
NADW exported at $20^{\circ} \mathrm{S}(\mathrm{Sv})$ & 13.7 & $13.6(0.8)$ & 13.5 & 13.7 & 13.6 \\
Max. Meridional overturning in Southern Ocean $(\mathrm{Sv})$ & 19.2 & $18.9(1.3)$ & 19.7 & 19.0 & 19.1 \\
\hline North Africa & & & & & \\
$\left(10^{\circ} \mathrm{W}-35^{\circ} \mathrm{E}, 15^{\circ} \mathrm{N}-30^{\circ} \mathrm{N}\right)$ & & & & & \\
Vegetation cover $(\%)$ & 27.5 & $53.4(1.9)$ & 67.1 & 55.0 & 53.9 \\
Surface albedo $(\%)$ & 34.3 & $28.8(0.4)$ & 25.7 & 28.5 & 28.7 \\
Temperature $\left({ }^{\circ} \mathrm{C}\right)$ & 24.2 & $24.4(0.1)$ & 24.5 & 24.4 & 24.4 \\
Precipitation $(\mathrm{mm} / \mathrm{yr})$ & 269.9 & $452.9(12.4)$ & 567.9 & 463.2 & 456.7 \\
\hline
\end{tabular}

under preindustrial forcings throughout the year (Renssen et al., 2005a, b). In the tropics, the largest difference between the two initial states is present over North Africa and Arabia, where the relatively high orbitally-forced summer insolation at $9 \mathrm{ka}$ results in stronger summer monsoons, enhanced precipitation and replacement of deserts by grasslands (Fig. 2a). These results are in general agreement with available proxy records (Renssen et al., 2005a, b).

Note that the $9 \mathrm{ka}$ conditions do not account for the remnant Laurentide Icesheet in North America. Renssen et al. (2005a) tested the impact of the elevated surface albedo and enhanced topography of this remnant Laurentide Icesheet on the climate of the early Holocene in ECBiltCLIO-VECODE. They found that including these effects results in a slightly cooler early Holocene climate, with the July temperature North of $60^{\circ} \mathrm{N}$ being $0.4^{\circ} \mathrm{C}$ lower than in an experiment without a Laurentide Icesheet. Using the same model, Wiersma et al. (2006) analysed the effect of the background meltwater flow from the early Holocene Laurentide Icesheet. They found that this meltwater causes a cessation of deep convection in the Labrador Sea, resulting in an overall weakening of the maximum meridional overturning in the Atlantic Ocean by $7 \mathrm{~Sv}$. This caused a cooling in the North Atlantic region, with a maximum temperature decrease of $2{ }^{\circ} \mathrm{C}$ in the Labrador Sea (Wiersma et al., 2006). After removal of this background meltwater flow, the model rapidly returned to a state with Labrador Sea deep convection. According to reconstructions (e.g., Peltier, 1994), the deglaciation of the Laurentide Icesheet was complete by $7 \mathrm{ka}$.

In addition to these equilibrium experiments, we performed a third simulation that was set-up as a transient experiment (6kTR). It was started from the same $9 \mathrm{ka}$ initial conditions as $6 \mathrm{k} 9 \mathrm{k}$, but was integrated forward in time towards preindustrial times, forced by annually changing values in 
(a) 9 ka minus preindustrial initial states

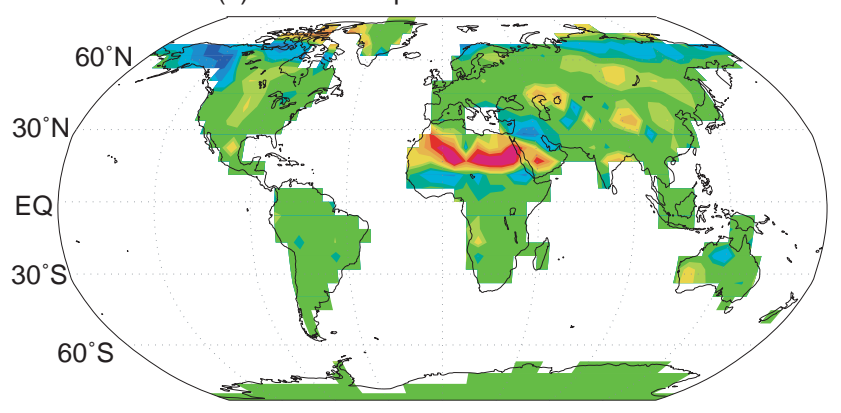

(b) 6 ka final minus preindustrial initial states

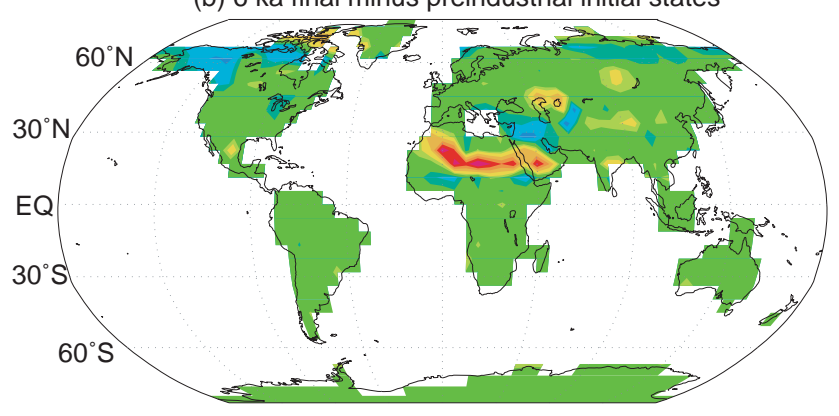

$\begin{array}{llllllllllll}-50 & -40 & -30 & -20 & -10 & -5 & 5 & 10 & 20 & 30 & 40 & 50 \%\end{array}$

Fig. 2. Simulated anomalies of mean fraction of surface covered by grassland (in \%). (a) $9 \mathrm{ka}$ minus preindustrial initial states, (b) $6 \mathrm{ka}$ final state (from 6kPI) minus preindustrial initial state.

orbital parameters and atmospheric concentrations of $\mathrm{CO}_{2}$ and $\mathrm{CH}_{4}$. At $6 \mathrm{ka}$, these values were identical to the ones prescribed in $6 \mathrm{kPI}$ and $6 \mathrm{k} 9 \mathrm{k}$. The level of $\mathrm{N}_{2} \mathrm{O}$ was kept constant at $262.3 \mathrm{ppb}$ throughout the $6 \mathrm{kTR}$ experiment. The results of 6kTR have been analyzed in detail for high-latitude climates (Renssen et al., 2005a, b, c).

\section{Results and discussion}

In our coupled atmosphere-ocean-vegetation system, the oceans are the component with the longest memory due to their large heat capacity. Consequently, any potential differences between our experiments that are caused by initial conditions and that are related to the memory of the system could be expected to be primarily present in the oceans. Therefore, we focus our global scale analysis on the oceans. For Northern Africa, we also consider vegetation because it has been suggested that in this region the vegetation-climate system could have two stable equilibria (i.e., "green" and desert) under 6 ka forcings. In the analyses, we consider a "final" $6 \mathrm{ka}$ state for which we take averages over the last 100 years of $6 \mathrm{kPI}$ and $6 \mathrm{k} 9 \mathrm{k}$, and the relevant 100 years of $6 \mathrm{kTR}$ (i.e. $6050-5950 \mathrm{yr}$ BP). Similarly, for the "initial" preindustrial and $9 \mathrm{ka}$ states, we use the 100-year averages at the end of
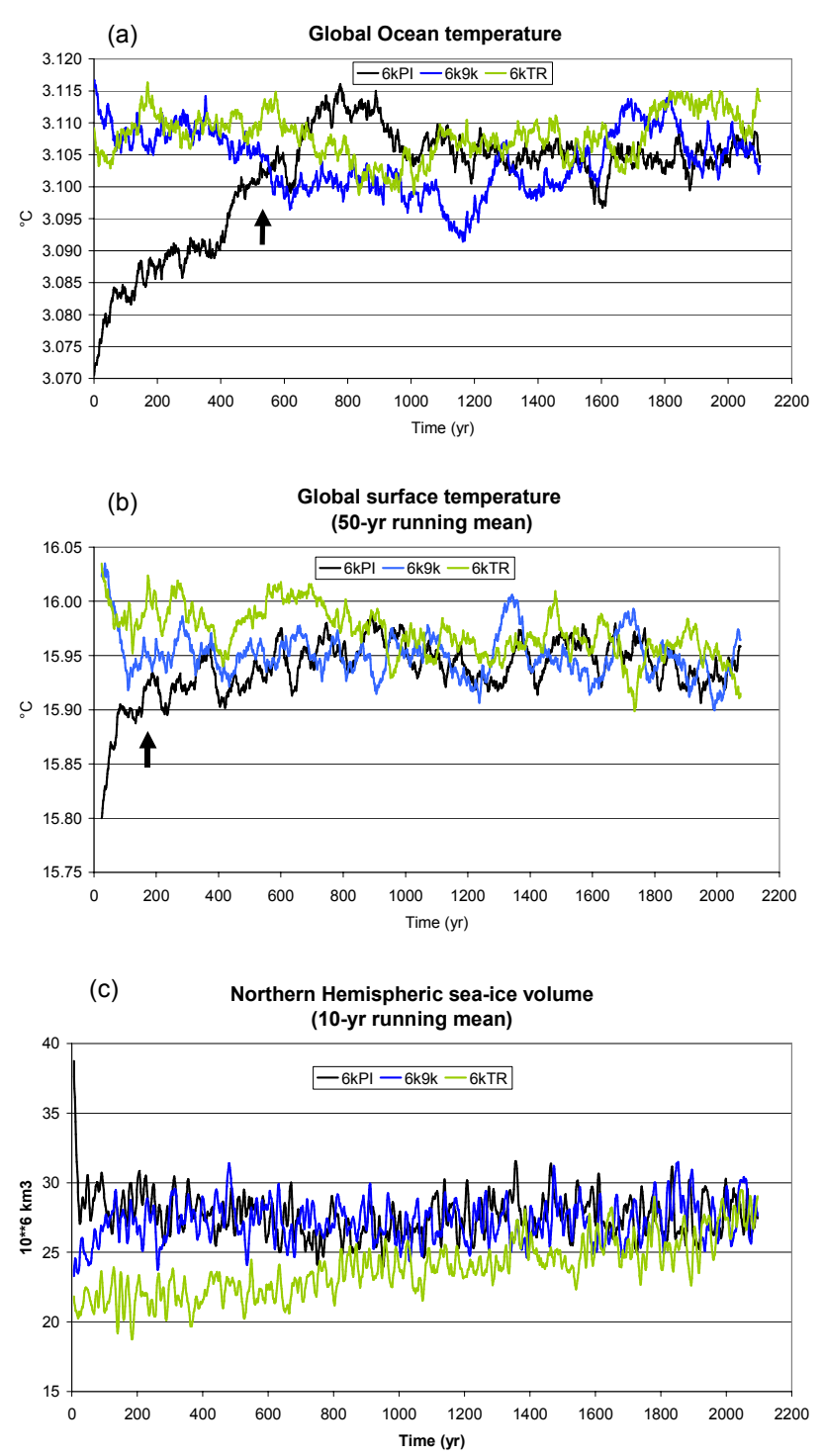

Fig. 3. Simulated annual means of the globally averaged ocean temperature (integrated over all depths, Fig. 3a, top), globally averaged surface temperature (Fig. $3 b$, middle) and sea-ice volume in the Northern Hemisphere (Fig. 3c, bottom). Note that the forcings for experiments $6 \mathrm{kPI}$ and $6 \mathrm{k} 9 \mathrm{k}$ are kept constant at $6 \mathrm{ka}$ values, while the forcings for 6kTR are changing every year. The shown values for 6kTR represent the period $8050 \mathrm{yr} \mathrm{BP}(\mathrm{t}=0)$ to $5950 \mathrm{yr} \mathrm{BP}$ $(\mathrm{t}=2100)$. The averages over the last 100 years are presented in Table 2. The arrows in Figs. 3a and 3b signify the moment where the shown temperatures of $6 \mathrm{kPI}$ reach the 2 -standard deviation level of the final $6 \mathrm{ka}$ average (defined as adjustment times, see text)

the equilibrium experiments with either preindustrial or $9 \mathrm{ka}$ forcings.

The globally averaged ocean temperature (i.e. integrated over all depth levels, Fig. 3a) provides a clear picture of the influence of the initial conditions and the time that is required to reach a new quasi equilibrium. On a global scale, the $9 \mathrm{ka}$ 
initial global ocean temperature is close $\left(3.12^{\circ} \mathrm{C}\right.$, see Table 2$)$ to the final $6 \mathrm{ka}$ state $\left(3.11^{\circ} \mathrm{C}\right)$, while the preindustrial climate is clearly colder $\left(3.07^{\circ} \mathrm{C}\right)$. A difference of $0.04^{\circ} \mathrm{C}$ might seem small, but one has to realize that this involves the entire volume of the global oceans, so that a huge amount of heat is involved (i.e. $2.2 \times 10^{23} \mathrm{~J}$, assuming a total ocean mass of $1.4 \times 10^{21} \mathrm{~kg}$, and a specific heat capacity of $\left.4 \mathrm{Jg}^{-1} \mathrm{~K}^{-1}\right)$. After about 550 years, the global ocean temperature is similar in $6 \mathrm{kPI}$ and $6 \mathrm{k} 9 \mathrm{k}$, and the levels are within the 2-standard deviation range of the final $6 \mathrm{ka}$ average. This implies that the influence of the cold initial preindustrial conditions is no longer discernible at the global scale. The temperature fluctuations in the remaining 1500 years of the experiments can be attributed to natural variability. The final level $\left(3.11^{\circ} \mathrm{C}\right)$ of the global ocean temperature in $6 \mathrm{kPI}$ and $6 \mathrm{k} 9 \mathrm{k}$ is the same as in 6kTR at $6 \mathrm{ka}$ (Table 2).

This is confirmed by latitude-depth profiles of global ocean temperature (Figs. 4a-b). As discussed in Sect. 2, the $9 \mathrm{ka}$ initial state is particularly warmer than the preindustrial initial state at high latitudes (Fig. 1a) under influence of the relatively high summer insolation values around this time (Renssen et al., 2005a, b). As a result the deep and intermediate waters formed at high latitudes are also warmer for the $9 \mathrm{ka}$ state than in the preindustrial case (Fig. 4a). An exception is formed by the northern tropics that are slightly cooler in the $9 \mathrm{ka}$ case. A comparison of the final states of $6 \mathrm{k} 9 \mathrm{k}$ and 6kPI (Fig. 4b) shows that this anomaly pattern has disappeared, which is consistent with Fig. 3a. The same is true for the final state of 6kTR (not shown).

Despite the difference in ocean temperature between the two initial states, the strength of the overturning circulation is similar in both the $9 \mathrm{ka}$ and preindustrial cases, and remains at the same level during the course of the experiments (Table 2). The export of North Atlantic Deep Water at $20^{\circ} \mathrm{S}$ is around $13.6 \mathrm{~Sv}$ in all cases. The maximum meridional overturning in the Southern Ocean shows some more variation (e.g. from 19.7 Sv to $19.0 \mathrm{~Sv}$ in $6 \mathrm{k} 9 \mathrm{k}$, Table 2), but this remains within the range of internal variability as indicated by the standard deviation (1.3) for the 6kPI final $6 \mathrm{ka}$ state (Table 1). To summarize, the differences in experimental setup between the considered simulations have no discernible impact on the final $6 \mathrm{ka}$ ocean state in our model.

As expected, the adjustment time at the surface is much shorter than for the entire global ocean. The levels of the global surface temperature (Fig. 3b) reach the same level in $6 \mathrm{kPI}$ and $6 \mathrm{k} 9 \mathrm{k}$ within 200 years. The same is true for the sea-ice volumes in both hemispheres (Fig. 3c, Table 2) and vegetation cover (not shown). The evolution of the global surface temperature and Northern Hemispheric sea-ice volume in 6kTR (Fig. 3c) reflects a gradual cooling as a result of the slow adjustment to the annually changing forcings in $6 \mathrm{kTR}$.

In addition to the discussed oceanic variables, we have also analyzed the spatial patterns of surface temperature, precipitation and vegetation cover anomalies. To see if the differ- (a) Ocean temperature anomaly $\left({ }^{\circ} \mathrm{C}\right), 9$ ka minus preindustrial initial states
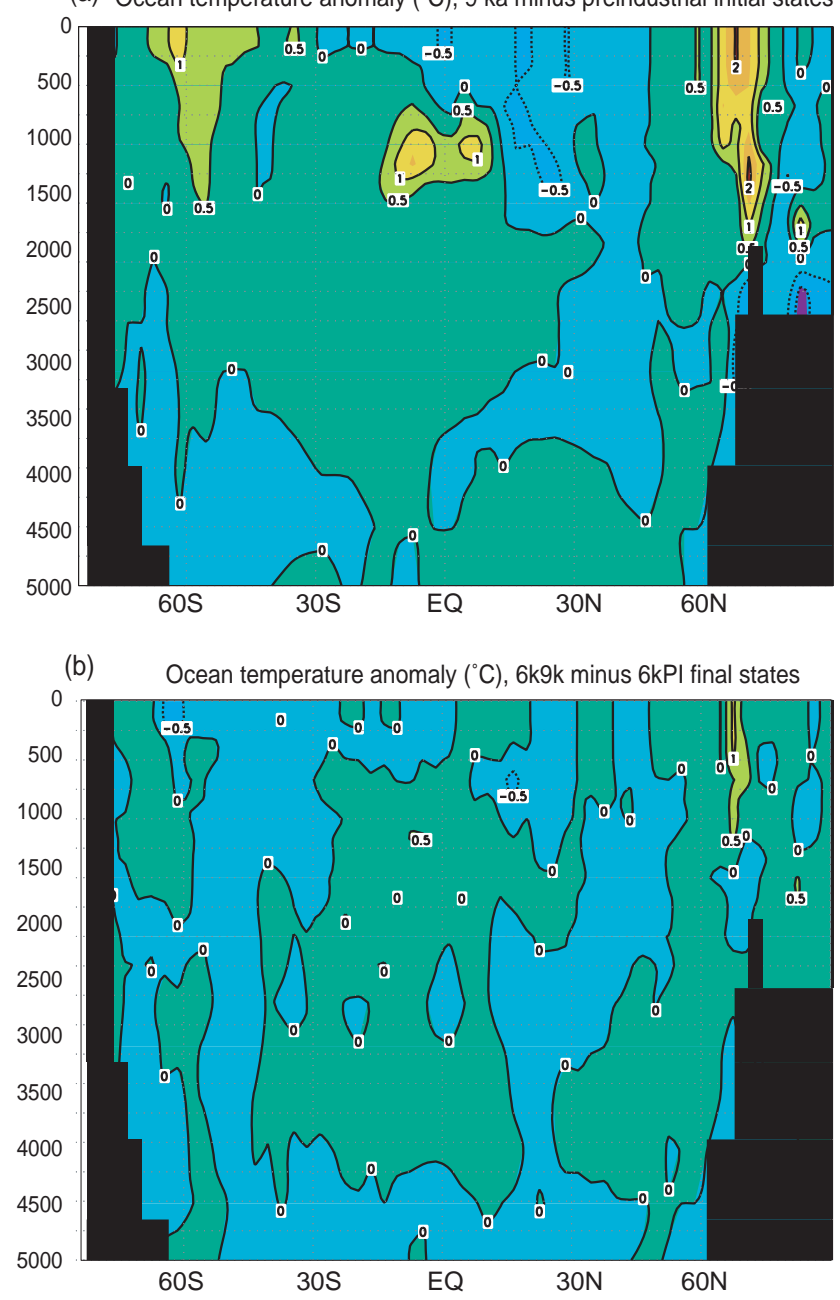

Fig. 4. Latitude-depth profiles for global ocean temperatures (in ${ }^{\circ} \mathrm{C}$ ). (a) $9 \mathrm{ka}$ minus preindustrial initial states, (b) $6 \mathrm{k} 9 \mathrm{k}$ minus $6 \mathrm{kPI}$ final states.

ences between the average $6 \mathrm{ka}$ climates were statistically significant, we performed a student-t test at the $95 \%$ level (not shown). In short, there were no consistent anomalies in surface temperature, precipitation or vegetation cover between the final $6 \mathrm{ka}$ states of $6 \mathrm{kPI}$ and $6 \mathrm{k} 9 \mathrm{k}$ that were statistically significant. As expected, the temperature and grassland fraction differences between the final $6 \mathrm{ka}$ states and the preindustrial initial state reveal similar patterns as observed for the difference between $9 \mathrm{ka}$ and preindustrial, but the magnitude of the anomalies is notably smaller (compare Figs. 1a and b, and Figs. 2a and b).

In Northern Africa, the initial conditions for vegetation differ considerably for $6 \mathrm{kPI}$ and $6 \mathrm{k} 9 \mathrm{k}$ (Fig. 2a). This is illustrated by the vegetation cover, which has a mean value of $27.5 \%$ in the preindustrial "desert" state and $67.1 \%$ in the $9 \mathrm{ka}$ "green" state (Table 2). In 200 years of simulation with $6 \mathrm{ka}$ forcing, $6 \mathrm{kPI}$ and $6 \mathrm{k} 9 \mathrm{k}$ converge at the $6 \mathrm{ka}$ level of 
$6 \mathrm{kTR}$ (i.e. vegetation cover of about $54 \%$, not shown). This is no surprise, as it was already noted that precipitation and temperature in $6 \mathrm{k} 9 \mathrm{k}$ and $6 \mathrm{kTR}$ show no consistent statistical anomalies over Northern Africa compared to 6kPI. Consequently, it may be concluded that in our model only the "green" state is stable over Northern Africa at $6 \mathrm{ka}$ and that initial conditions have no distinct impact on the 6 ka vegetation in this region.

It should be noted that this conclusion for Northern Africa is model-dependant. For instance, in an earlier model version (ECBilt-CLIO-VECODE version 2), both desert and green states were potentially stable in Northern Africa under $6 \mathrm{ka}$ forcings, in addition to an intermediate unstable state (Renssen et al., 2003). In a transient experiment identical to $6 \mathrm{kTR}$ that was performed with this previous version, stochastic variations in precipitation were able to induce pronounced centennial-scale transitions between the green and intermediate states from 7.5 to $5.5 \mathrm{ka}$ in the western part of Northern Africa (between $15^{\circ} \mathrm{W}$ and $5^{\circ} \mathrm{E}$, Renssen et al., 2003, 2006). This instability is related to Charney's biogeophysical feedback (Charney, 1975; Charney et al., 1975) between surface albedo, influenced by vegetation cover, and precipitation. Compared to the experiment with version 2, in 6kTR the Holocene desertification in Northern Africa differs on two points. First, the largest change from "green" to desert takes place more to the east (i.e. in the central-eastern Sahara between $10^{\circ} \mathrm{E}$ and $35^{\circ} \mathrm{E}$ ), and second, the unstable phase with accelerated desertification due to Charney's biogeophysical feedback occurs later (i.e. between 5.2 to $3.2 \mathrm{ka}$ ). Consequently, at $6 \mathrm{ka}$ the climate in $6 \mathrm{kTR}$ is still in the "green" state. In the ECHAM-BIOME model, the "green" state is also the only equilibrium that exists under 6 ka forcings (Brovkin et al., 1998). However, it should be noted that we cannot be certain that the sensitivity for Holocene forcings is more correct in ECBilt-CLIO-VECODE version 3 (or ECHAM-BIOME) than in version 2.

The similarity between the $6 \mathrm{ka}$ climates in $6 \mathrm{kTR}$ and the other experiments (6kPI and $6 \mathrm{k} 9 \mathrm{k}$ ) implies that the climate in $6 \mathrm{kTR}$ is in equilibrium with the $6 \mathrm{ka}$ forcings, suggesting that the annual changes in forcing are small enough for the system to adjust continuously during the mid-Holocene. In other words, assuming an adjustment time (or memory) of $\sim 550$ years, the climate at $6.0 \mathrm{ka}$ is still influenced by the forcings at $6.6 \mathrm{ka}$ in $6 \mathrm{kTR}$, but the changes in forcings between $6.6 \mathrm{ka}$ and $6 \mathrm{ka}$ are apparently not large enough to yield a statistically different climate compared to $6 \mathrm{kPI}$ and $6 \mathrm{k} 9 \mathrm{k}$. This is good news for model-data comparisons as carried out for the 6 ka climate within PMIP (e.g., Joussaume et al., 1999), as one can expect that the climatic changes experienced in the "real world" (as registered in proxy data) are closer to the results of 6kTR than to those of the other experiments.

One should be cautious, however, as it is uncertain to what extent our inferences are applicable to other models. Compared to comprehensive general circulation models, our model has a number of simplifications - especially in the at- mospheric component ECBilt - which could have influenced the results. For instance, ECBilt has a relatively low spatial resolution (T21 with 3 layers) and is based on quasigeostrophic equations. The model is therefore not particularly suitable to simulate the climate at low latitudes. Another important simplification is the prescription of cloud cover according to present-day climatology.

If we assume that our inferences about the indiscernible influence of initial conditions are correct, it would imply that the PMIP protocol for $6 \mathrm{ka}$ experiments is valid. An important requirement is that the integration time during spin-up allows for adjustment of deep oceans to the $6 \mathrm{ka}$ forcings. If we define this adjustment time as the moment at which the global ocean temperature is within the 2-standard deviation range of the final $6 \mathrm{ka}$ average, our simulations suggest that the spin-up phase should at least have a duration of 550 years (Fig. 3a). In our experiments, the adjustment time at the surface is about 200 years if we consider a 50 -year running mean of the global surface temperature (Fig. 3b). This is also the time-scale found for vegetation. If we assume that the adjustment of the deep ocean is more or less linear (as suggested by Fig. 3a), the error made by doing 200 years of spin-up would be about two-thirds of the difference between the used initial state and the final 6 ka equilibrium state.

\section{Concluding remarks}

In our model, the initial conditions (either preindustrial or early Holocene) have no discernible impact on the final $6 \mathrm{ka}$ climate that is obtained after running our model for 2100 years with constant forcings for $6 \mathrm{ka}$. After about 550 years, both $6 \mathrm{kPI}$ and $6 \mathrm{k} 9 \mathrm{k}$ have reached the final level of deep ocean temperature that is matching the $6 \mathrm{ka}$ level in our transient experiment 6kTR. The vegetation in Northern Africa reaches the same $6 \mathrm{ka}$ level after about 200 years in both the equilibrium experiments with different initial conditions, giving no indication for instability of the vegetation-atmosphere system under $6 \mathrm{ka}$ forcings. Assuming that these conclusions are applicable to other models, our results suggest that the PMIP setup for $6 \mathrm{ka}$ experiments is reasonable as long as the experiments have a long enough spin-up time (i.e. at least 550 years) to account for the relatively slow response of the deep ocean.

Acknowledgements. The useful comments of J. Hargreaves and two anonymous referees are gratefully acknowledged. H. Renssen is supported by the Netherlands Organization for Scientific Research (NWO). This study was carried out as part of the Belgian Second Multiannual Scientific Support Plan for a Sustainable Development Policy (Belgian Federal Science Policy, contract EV/10/9A), the Belgian Research Programme on Science for a Sustainable Development (Belgian Federal Science Policy, contract: SD/CS/01A) and the European Research Programme on Environment and Sustainable Development (European Commission, contract EVK2-CT-2002-00153). V. Brovkin (Potsdam Institute 
for Climate Impact Research) kindly made VECODE available for this study. J. M. Campin (MIT) is thanked for programming the coupling of VECODE to ECBilt and for model testing.

Edited by: J. Hargreaves

\section{References}

Berger, A. L.: Long-term variations of daily insolation and Quaternary climatic changes, J. Atmos. Sci., 35, 2363-2367, 1978.

Brovkin, V., Claussen, M., Petoukhov, V., and Ganopolski, A.: On the stability of the atmosphere-vegetation system in the Sahara/Sahel region, J. Geophys. Res., 103, 31 613-31 624, 1998.

Brovkin, V., Bendtsen, J., Claussen, M., Ganopolski, A., Kubatzki, C., Petoukhov, V., and Andreev, A.: Carbon cycle, vegetation and climate dynamics in the Holocene: experiments with the CLIMBER-2 model, Global Biogeochem. Cycles, 16, 1139, doi:10.1029/2001GB001662, 2002.

Charney, J. G.: Dyamics of deserts and droughts in the Sahel, Quart. J. Roy. Meteorol. Soc., 101, 193-203, 1975.

Charney, J. G., Stone, P. H., and Quirk, W. J.: Drought in the Sahara: a biogeophysical feedback mechanism, Science, 187, 434-435, 1975.

Crucifix, M., Braconnot, P., Harrison, S. P., and Otto-Bliesner, B.: Second phase of Paleoclimate Modelling Intercomparison Project, EOS, 86, No. 28, 12 July 2005.

deMenocal, P., Ortiz, J., Guilderson, T., Adkins, J., Sarnthein, M., Baker, L., and Yarusinsky, M.: Abrupt onset and termination of the African humid period: rapid climate responses to gradual insolation forcing, Quat. Sci. Rev., 19, 347-361, 2000.

Gent, P. R. and McWilliams, J. C.: Isopycnal mixing in ocean general circulation models, J. Phys. Oceanogr., 20, 150-155, 1990.

Goosse, H. and Fichefet, T.: Importance of ice-ocean interactions for the global ocean circulation: a model study, J. Geophys. Res., 104, 23 337-23 355, 1999.

Hoelzmann, P., Jolly, D., Harrison, S. P., Laarif, F., Bonnefille, R., and Pachur, H.-J.: Mid-Holocene land-surface conditions in northern Africa and the Arabian peninsula: a data set for the analysis of biogeographical feedbacks in the climate system, Global Biogeochem. Cycles, 12, 35-51, 1998.

Joussaume, S. and Taylor, K. E.: The Paleoclimate Modelling Intercomparison Project, in: PMIP, Paleoclimate Modeling Intercomparison Project (PMIP): Proceedings of the third PMIP workshop, Canada, 4-8 October 1999, edited by: Braconnot, P., WCRP-111, WMO/TD-1007, p. 9-25, 2000.
Joussaume, S., Taylor, K. E., Braconnot, P, et al.: Monsoon changes for 6000 years ago: results of 18 simulations from the Paleoclimate Modeling Intercomparision Project (PMIP), Geophys. Res. Lett., 26, 859-862, 1999

Opsteegh, J. D., Haarsma, R. J., Selten, F. M., and Kattenberg, A.: ECBILT: A dynamic alternative to mixed boundary conditions in ocean models, Tellus, 50A, 348-367, 1998.

Peltier, W. R.: Ice age paleotopography, Science, 265, 195-201, 1994.

Prentice, I. C.: The climate and biomes of Europe at $6000 \mathrm{yr}$ BP: comparison of model simulations and pollen-based reconstructions, Quat. Sci. Rev., 17, 659-668, 1998.

Prentice, I. C., Jolly, D., and BIOME 6000 participants: MidHolocene and glacial-maximum vegetation geography of the northern continents and Africa, J. Biogeogr., 27, 507-519, 2000.

Raynaud, D., Barnola, J.-M., Chappellaz, J., Blunier, T., Indermühle, A., and Stauffer, B.: The ice record of greenhouse gases: a view in the context of future changes, Quat. Sci. Rev., 19, 9-17, 2000.

Renssen, H., Brovkin, V., Fichefet, T., and Goosse, H.: Holocene climate instability during the termination of the African $\mathrm{Hu}-$ mid Period. Geophys. Res. Lett., 30, 1184, doi:10.1029/ 2002GL016636, 2003.

Renssen, H., Goosse, H. Fichefet, T., Brovkin, V., Driesschaert, E., and Wolk, F.: Simulating the Holocene climate evolution at northern high latitudes using a coupled atmosphere-sea iceocean-vegetation model, Clim. Dyn., 24, 23-43, 2005 a.

Renssen, H., Goosse, H., Fichefet, T., Masson-Delmotte, V., and Koç, N.: The Holocene climate evolution in the high-latitude Southern Hemisphere simulated by a coupled atmosphere-sea ice-ocean-vegetation model, Holocene, 15, 951-964, 2005 b.

Renssen, H., Goosse, H., and Fichefet, T.: Contrasting trends in North Atlantic deep-water formation in the Labrador Sea and Nordic Seas during the Holocene. Geophys. Res. Lett., 32, L08711, doi:10.1029/2005GL022462, 2005c.

Renssen, H., Brovkin, V., Fichefet, T., and Goosse, H.: Simulation of the Holocene climate evolution in Northern Africa: the termination of the Afican Humid Period, Quat. Int., 150, 95-102, 2006.

Wiersma, A. P., Renssen, H., Goosse, H., and Fichefet, T.: Evaluation of different freshwater forcing scenarios for the $8.2 \mathrm{ka}$ BP event in a coupled climate model, Clim. Dyn., in press, doi:10.1007/s00382-006-0166-0, 2006. 